\title{
The Influence of Classroom Environments on English Language Writing Instruction and Learning
}

\author{
Nancy R. Nabiryo \\ Makerere University, Kampala, Uganda \\ Samuel Sekiziyivu \\ Makerere University, Kampala, Uganda
}

\begin{abstract}
Writing is one of the four language skills. Writing plays a big role in helping individuals clarify their thoughts, to the nation for storing information and in the academic world for taking notes and expressing logical arguments. Unfortunately, society still complains that school leavers do not know how to write indicating that either they were not taught writing or that the classroom environments where they were taught were not adequate enough to prepare them for the kind of writing they would need after school. This paper explores the influence of classroom environments on the teaching and learning of writing in secondary schools. Using a qualitative multiple case study design, we collected data from three schools through lesson observation and interviewing teachers and learners. Data were analyzed according to the emerging themes which were; classroom displays, lighting, and air. Findings portrayed that there were different teaching and learning environments but the success of writing instruction depended on how teachers modified the classroom environments to suit the different topics they were teaching. Therefore, there is a need to maximize the classroom environments to enhance writing instruction and learning.
\end{abstract}

Index Terms — classroom environments, writing instruction, writing learning

\section{INTRODUCTION}

Writing is the presentation of clear coherent well- organized work on paper that suits one's intended audience and purpose. This means that people write because of different reasons and audiences. In terms of the intended audience, the reader determines the style, the organization, the topic and the choice of words that the writer feels will best convey their message. Writing serves a variety of purposes. It helps one articulate their thoughts feelings and plans, is good for clarifying, organizing thought and plans and conveying one's ideas in a logical and credible way among others. In school, writing is an integral part of all subjects and many of the exams done in secondary schools require learners to answer questions in writing implying that the success of the student in school is determined by how well they express themselves.

Good writing skills involve the use of clear and concise language that conveys information in a way that is easily understood by the intended audience. Good writing enables learners to express themselves accurately and confidently. It also enables learners to have a sense of readers' expectations, and an awareness of conventions for a particular piece of writing. This is the reason why there is a need to study how learners develop good writing skills through writing instruction.

Globally, writing instruction has undergone different changes. According to the online Education encyclopedia, written composition became a concern for American High Schools in the late $19^{\text {th }}$ century as high schools focused on preparing an elite group of males for universities, a task that would increase demand attention to writing. The year 1873 marked a turning point as Harvard University started demanding that each candidate applying to study writes a composition about a literary work. The focus was on enabling each pupil to give expression to his/her own thoughts which led to the teaching of composition. Throughout the $20^{\text {th }}$ century, learners were commonly assigned essays in form of description and narration following the rhetorical traditions of the $19^{\text {th }}$ century. Teachers taught lessons based on the ideal written work which focused on words and learners were graded on how close they met the ideal. The next development was the 1966 Dartmouth conference which brought together leading American and British specialists in the teaching of English and suggested that assigning and grading writing was not enough. The 1966 Dartmouth conference also suggested that learners should be supported through the writing process of generating ideas, reflection, planning and composing. This led to the 1981 Flower and Hayes cognitive process model which studied how expert writers compose their texts with a view of using this method to teach learners the composing process. Later, new trends emerged which led to the recognition that writing is judged according to how much it reflects consideration of audience, purpose, and occasion. As a result, researchers started studying classrooms and rhetorical contexts where writing instruction takes place. Other trends focused on the composting process and how teachers at different levels support 
diverse writers and how writing supports learning across the curriculum. The $21^{\text {st }}$ century has portrayed increasingly lower writing achievements among learners without American and European descent. It has also led to the technological revolution as computers provide support for writers.

According to Ssebbunga-Masembe (2001), writing instruction in Uganda began with the missionaries who came to Uganda between 1877 and 1879. As their focus was on teaching literacy in order to train good Christians, the missionaries only taught basic reading and writing. Ojijo (2012) explains that the colonialists who took over education from the missionaries aimed at training low and mid-level manpower for administration. Thus writing instruction during the colonialists' time focused on training basic skills of spelling, grammar, and punctuation which would not require much thought or attention. Most of the commissions that came after independence did not change much in writing instruction. Writing instruction focused on teaching learners how to write essays but not skills required in writing for different purposes or audiences. However, according to the Education Sector Strategic Plan (ESSP) 2004-2015, learners were taught how to write but they were not equipped to write in ways that would enable them to write for different audiences. The history of writing and writing instruction shows that the reasons, emphasis, and content of writing and writing instruction have been evolving according to different societal needs. It is only towards the end of the $20^{\text {th }}$ century that the need to look at the process of writing while paying attention to audience, purpose, and intention was recognized. Even then, in Uganda, these elements have not yet been considered when teaching secondary school writing.

Scholars like Kyalikunda (2005) and Karooro Okurut (2000) noted the deteriorating standards of English in Uganda. This is evident in the poor expressions used by speakers in interviews, directing visitors and writing application letters. They argue that learners' lack of communication competence is evident in school leavers' poor reading/comprehension skills, poor oral communication skills, and poor writing skills. Learners come through years of schooling being taught writing but they are being unable to write to suit the employer's needs suggests that they either have not been taught effectively or the content, methods and writing environment are not appropriate. If we do not improve the teaching of writing, we will continue to invest in educational resources like time; money, classrooms, and teachers without enabling learners to demonstrate mastery writing. The available literature documents that the teacher's knowledge of writing content and how to teach writing, the physical and emotional state of both learners and the teacher, as well as the ability of both learners and teacher to interact appropriately with each other and with their physical classroom environments all, contribute to mastery of writing. It suggests that the place of young adolescents in this classroom and their writing needs have not been addressed when teaching writing. The physical writing environment should not be neglected if we are to improve writing instruction. This paper considered how the physical classroom environments in secondary schools influenced the teaching and learning of writing among young adolescents.

To better understand the value of physical classroom environments on teaching writing, this research was informed by Vygotsky's 1978 Constructivist theory. According to Vygotsky, learning is a social process whose origins are in human cognition. Children develop a language with the need to communicate and only later do they use it to organize thought. Therefore, the social needs of language precede personal needs. According to Turuk (2008), social-cultural settings act as primary and determining factors for higher forms of human activity like voluntary attention, logical thought and problem-solving (P.245). The social level, as far as the learning of writing is concerned, involves the learner's interaction with their teacher, fellow learners, and the environment. This interaction takes place when the class is comfortable, the teacher is knowledgeable about their content and encourages learners to discuss the writing task with the teacher and fellow learners. The level of comfort in classes all forms part of the classroom environment we were concerned about in order to find out whether teachers of writing endeavor to make their physical classes as conducive to writing learning as possible. Vygotsky's constructivist theory was chosen as it deals with how the physical environment influences writing instruction.

This paper focused on the understanding value of the physical classroom environments in which writing instruction and learning take place. The physical classroom environments studied in this paper were: the nature of classroom displays, lighting and aeration while writing instruction encompassed the teacher's attitude and all the means by which the teacher teaches writing.

\section{PURPOSE OF THE STUDY}

The purpose of this study was to describe the worth of physical classroom environments on English language writing instruction and learning among young adolescents. The following question guided this research "What is the value of physical classroom environments on English language writing and learning among young adolescents?"

\section{METHODOLOGY}

This study followed a qualitative multiple case study design. According to Creswell (2014), case study designs involve an in-depth analysis of a case or cases. Yin (2009) explains that case studies are used to answer how or why questions where we have little control of events and to investigate the contemporary phenomenon. Yin further explains that there are two types of case studies: single and multiple case studies. Multiple case studies are where one studies different units of analysis or different cases. We chose a multiple case study design in order to make a comparative 
analysis on how the different physical classroom environments influenced English language writing instruction and learning.

Three schools in Uganda were selected. The schools were chosen basing on the following categories. School one was chosen because it was a private school following whose learners were the being prepared to sit for the national exams. Because it was private, it attracted few learners of relatively low-income status and could not afford to pay teachers well. We chose it because we wanted to find out the influence of physical classroom environments on writing instruction in an underfunded school. The second school was a government aided Universal Secondary Education School in which learners were not paying any fees and the government catered for all the school's expenditure. As learners were not paying any fees, we wanted to study how the available physical environment facilities in the classrooms influenced writing instruction. The third school was an international school which attracted learners of high social economic status. It was categorized as international because it attracts learners from all over the world and because learners are free to choose whether to study the Uganda Syllabus or Cambridge one. Due to time and financial constraints, only three schools were selected. The teachers were purposively selected. That is, all the teachers selected were teaching Senior One to Senior Three English writing and had at least three years of teaching writing at secondary school. Since writing instruction is done by teachers, these were chosen as part of the classes to provide information on their teaching methodology and how their physical classroom environments influenced writing instruction and learning. All learners in the selected classes were observed as writing instruction was going on. The teachers helped us choose a group of six learners in from the relevant classes in each school to participate in focus group discussions. The focus group discussions centered on issues about how their interaction with their physical classroom environments during writing instruction and learning improved students' writing quality.

The instruments used were lesson observation guides, interview guides, and documentary analysis. Observation guides generated first-hand information on the influence of the classroom displays, air movement, and light on writing instruction and learning. Lessons were observed to follow up on any information provided in the interviews. A total of forty writing instruction lessons were observed. Interview guides were used to gather information regarding teachers' perceptions of the influence of displays, light, and aeration on the teaching and learning of writing. Six learners from each school were interviewed. They were interviewed during a group interview on their views on the right environments to learn writing and to write. The documentary analysis enabled us to triangulate data from interviews, group interviews, and lesson observations. Teachers' Schemes of Work, lesson notes and Records of Work were studied to see if the planned for displays and writing content and methodology in their documents matched with those they had talked about in the interviews.

This research ensured the validity of instruments by a clear description of the physical classroom environments and writing instruction, by citing other researches which studied classroom environments and writing instruction and by going to different schools, classes and conditions in order to triangulate the data and check for its accuracy. Reliability was ensured through a clear demonstration of all the steps in data collection, from schools with different classroom environments.

During data collection, we first sought permission from the relevant authorities like head teachers and teachers who were teaching senior one to senior three and who were willing to participate in the study. After this, they then proceeded to interview the teachers, analyze their records and observe their lessons. Most of the teachers were interviewed on school compounds and the interviews were tape recorded with teachers' permission. Then we interviewed learners using group interviews and studied their notebooks. At the end of each data collection day, we would transcribe the data obtained. Data was assembled, coded, analyzed and interpreted, first, according to the different research instruments, secondly, according to emerging themes and thirdly, according to the objective. It was categorized according to the influence of classroom displays, lighting and air on writing instruction.

Ethical issues were maintained through seeking permission from head teachers before carrying out research in their schools. Teachers were informed of the purpose of the research and why they were chosen to participate in it (Punch 2012). They were given the option to either participate in the study or not. They were assured of the confidentiality of information and that the research would use pseudo names. All lesson observations took place with the teachers' consent. In order to protect learners, their identities during focus group discussions were only known by the researchers and all participants were assured that the data would only be used for this study.

\section{RESUltS}

In this study, we researched the value of physical classroom environments on writing instruction and learning. Data portrayed that many classrooms in Uganda have four walls, a roof, a chalkboard hanging at the front, display boards, windows, and a door. We took notes on the nature of lighting, the air in the classrooms, the nature of displays, and how all these influenced writing instruction. We did this because the writing process involves so many tasks that a writer requires a well lit, conducive physical environment that fosters concentration on the writing tasks. As we analyzed data using the interpretive approach, the following themes emerged; "classroom displays", "Influence of light on writing learning", and "Influence of well-aerated classrooms on writing instruction".

\section{A. Classroom Displays}


This is where teachers displayed key information on writing instruction, content, and styles for learners to constantly study until it was fixed in their long-term memories for later retrieval. Of the three schools, we collected data from; two barely had writing displays to support writing much as some of the teachers in these schools said displays helped a lot. For example, in talking about his ideal classroom environment ET01 from Everest High School said:

I would like to see a classroom which has materials in the class, a number of sample materials. I don't know how we can do it because every subject would be competing for their materials hanging in class. (Teacher's Interview 2 School 1)

ET01 professed that displaying writing materials could help in teaching writing though he did not think he could have them in his classrooms as this would generate competition for space from other subjects. However, the bare walls in his classroom showed that no other subject teacher wanted to display any content. The bare walls in his classroom portrayed that ET01's fear for competition from other subject areas was unfounded. This implied a theoretical view of the importance of displays basing on the fact that we did not see any display he had prepared for his classes. Therefore, though some teachers professed to see the value of having displays on writing instruction in the classroom, the fact that they did not have any in their classes implies that displays had no influence on writing instruction.

In contrast to School 1 and School 2, all the classrooms in School 3 that we entered had displayed. This was part of the school culture as KT03 told me in the interview. She said the nature of displays in a classroom depended on the subject the room teacher was teaching. For example, in KT01's room also known as the English room, the displays included a chart showing some examples of American and British English and how to write a formal letter. KT02's room had a notice board with lists of idioms and the structure of English exams. During writing lessons, at no point did we see any teacher refer to the different displays yet when we interviewed them they were full of praises for displays, for example, KT01 enthusiastically said;

Displays. Display phrases, idioms, and proverbs. Even display sample stories, learners work or even general proverbs, similes, figurative expressions, and their meanings. Then we display their work. Margaret writes an interesting story, using all the descriptive words, the figurative expressions, the right adjectives, we shall display it. Somebody comes and look, I can write this like this. I write this simile like this. They relate easily to their work. (Teacher's Interview 5 School 3)

KT01's comment above showed that she values displays. She also seemed to believe that a well-written story should have descriptive language, use of figurative language and idioms, proverbs and similes. However the fact that she says 'we shall display it' shows that she had not yet displayed the work evidently because she does not practice what she claims to believe. Indeed when we entered her class, we did not see any display of learners' work, a sign that her belief in the value of learners work was theoretical. Even the sentence, 'Somebody comes and look, we can write like this.' Shows that as a teacher, KT01 does not go out of their way to draw attention to the displays but imagines that learners will just be attracted to anything on the walls. In observing her writing lessons, at no point did we observe her drawing her learners' attention to the lists of American and British English displayed on the walls. Therefore, in her case, the presence of displays in the classroom environment did not directly influence writing learning

In this section, we have analyzed the findings on the influence of classroom displays on writing instruction. The analyzed findings also show that while many teachers saw the value of having displays in class; these were rarely used in the practical teaching of writing a sign that the presence of displays had little influence on writing instruction.

\section{B. Influence of Light on Writing Learning}

In order to write well, and clearly, one needs to work in a well lit. All schools ensured that their classrooms supported writing learning and instruction with varying levels of success. In collecting data under this, we considered how the general appearance of the room that is, the color of the walls, and the windows provided lighting that either enhanced or hindered effective writing instruction. Data in this sub-section was obtained from lesson observations and focus group interviews.

Classes which were well lit supported writing learning for instance, in School 1, the class had big windows at one side, unpainted grey walls and a small bulb whose light was on all the time. All these created a well-lit classroom which fostered easy reading and transfer of the content ST01 was writing on the board. ST01's method of teaching involved writing formats of formal documents on the board which her students were supposed to read as they transferred them to their books. The presence of lighting in the rooms enabled learners to see and read what ST01 had written on the board before transferring it to their books. All these processes required and lit rooms which enabled learners to focus when or taking down dictated notes. Thus, in School 1, the fact that the classroom was well lit supported note taking but it did not develop any writing learning.

All classes in School 2 had electric bulbs which were on for most of the day and big windows which covered most of the walls on one side of the room and dark green walls. The big windows on one side of the room provided light which, in conjunction with the electricity in the room enabled learners to focus clearly on the teacher and the key points some of the teachers in this school would write on the board as well as see what they were writing during the translation process. However, in some lessons, these big windows easily provided distractions to learners. For example, one of the senior two classrooms had big windows opening up to a playground. During the time ET03 was teaching formal letter writing, we noticed that some learners' attention was taken by the activities a physical education activity some learners from a neighboring school were having on the playground. Thus, though the presence of big windows provided good 
lighting, the fact that they opened up to a playground which had constant activity, interfered with learners' concentration on the writing topics thus preventing effective learning of writing.

Though the senior three classrooms in the same school had similar features like the senior two classrooms, their windows had purple curtains and, learners would hang their school bags on hooks attached to the windows. The combination of these two aspects made the classes too dark and stuffy for learners to focus on the writing content generated on the chalkboard and on their writing. This made learners sitting at the back to strain their eyes to follow the writing lessons thus rendering learning these writing lessons less effective. For example, when ET02 was teaching minute writing, she introduced the lesson by writing the title 'Writing Minutes of a Meeting' on the chalkboard. We noted that some learners at the back were not writing while other learners were trying to strain their eyes to read the topic and copy it down thus preventing them from following the other aspects of the writing lesson. Writing the title of a lesson is supposed to focus learners' attention to the various areas of writing which range from the format of the document being learned, its content as well as the spellings, grammar, and punctuation of all words written on the board. Thus a student who strains to read the title will focus on the lower order writing aspects of orthography at the expense of learning the higher order writing skills of form, content, and purpose of writing. Curtains were left in windows to remove any distractions in form of activities taking place outside the classrooms. Learners' bags were hanging on windows because these being classes with large numbers of learners, the learners had nowhere to keep their bags. However, their combination created made the class dark to the extent that some students at the back could not see what the teacher was teaching. This was also echoed by some learners for example when asked about his ideal writing environment, Robert said, 'One which is not too dark' implying that dark places prevented him from seeing what he was writing thus affecting his written work. Kate described a well-lit environment as a place "where there is no too much sunshine' implying that too much light affected her visibility thus preventing her from seeing what she was writing. Therefore, adequate light supported writing learning as it enabled learners to see the writing content and concentrate on the writing tasks.

The classroom design of School 3 was made in such a way that the classes had enough light while taking away any possible distractions to writing instruction. All their classrooms had light green walls, white ceilings and white tiled floors- colors all which reflected light thus creating a well-lit atmosphere which motivated learners to concentrate on the writing lessons at hand. Though the classes had big low windows which allowed in sunlight, the windows faced places which had no activity during class time. The teachers in our study on most occasions made their learners sit facing the center of the room and the whiteboard thus reducing the chances of their being distracted by any activity out of the room. For example, for all the lessons we observed in this school, only once did I see learners being distracted by an activity out of the room. This was the time when KT03 was teaching Senior One's how to use idioms, at the time she had told the class to generate sentences using specific idioms she had written on the board, I saw some learners looking out of the window where some people were setting up a phone booth. This prevented them from writing the idioms the teacher had told them until she saw them and drew their attention to the task at hand. Thus though KT03 tried to influence writing learning by making her learners sit with their backs to the windows, in cases where classrooms had big windows and there were activities going on out of class, effective writing learning was hindered.

In a nutshell, data collected portrayed that lighting was provided through windows, the color of the walls and electric bulbs. Adequate lighting influenced writing instruction and learning by enabling learners to see both the writing content shown on the blackboard and what they were transcribing. But where the windows faced a busy noisy place, were shut or had curtains, they provided distractions or made the classroom too stuffy and dark for writing instruction and learning to be effective.

\section{The Influence of Well-aerated Classrooms on Writing Instruction}

Well, aerated classrooms are rooms that provide free movement of air. This can be done through air conditioning or by providing enough open windows and ventilation. These have the potential of making learners and teachers feel comfortable thus concentrating on writing learning and instruction. Different classrooms achieved this with varying degrees. Data from this section was obtained from lesson observation and interviews with both teachers and students.

In all classrooms, aeration was provided by big windows which occupied either one whole wall or two sides of the classroom. The senior three classrooms of School 2 had similar features like the senior two classrooms but their windows had purple curtains and learners would hang their school bags on hooks attached to the windows. However, the combination of purple curtains and windows covered with school bags created stuffy, hot environments in the classrooms that affected students' morale in writing. ET02 noted the stuffiness in the classroom when she said students were not motivated to write. And KT01 said:

If a child is not comfortable, they are not going to be encouraged to write. Maybe they will write half way and stop; because they are not comfortable anyway. (Teacher's Interview 4 School 3)

KT01 said students' level of comfort affected their writing motivation. Part of this comfort could be influenced by the level of aeration. The need for comfort and well-aerated environments was echoed by most of the students I interviewed for example; when asked about their ideal writing environment some students said:

Davis: I can write in circumstances when I feel cool like even the atmosphere must be somehow cool.

Daniel: When I am in the balcony, I am writing about the future and the present. When I am in the garden, I am writing about feelings. I am writing about things that make me emotional. 
Janet: There are some environments you want to write in but can't access. So you feel like you want to imagine them. You feel inspired and like when you are in the flower garden alone. (Interview 3 S.2 FGD)

The students above used a variety of images to describe well-aerated environments for example, 'cool' 'a balcony' and 'a garden'. What all these have in common is the free movement of air. For Daniel and Davies well-aerated environments' supported writing learning enhanced the process of providing conducive atmospheres for translating already generated ideas on paper while for Janet, it is in the inspiration when generating ideas. Thus well-aerated environments supported writing learning and writing itself by making the learners comfortable.

In summary, well-aerated classrooms enhanced writing and writing instruction where there are no distractions. The presence of big windows in some classes which provided and fresh air made the environment cool and conducive to concentrate on generating ideas and writing. But where the windows were shut or had curtains, they provided distractions or made the classroom too stuffy for writing instruction and learning to be effective.

\section{Discussion OF FINDINGS}

This study analyzed the influence of physical classroom environments on writing learning. Specifically, we studied the influence of displays, adequate light and well-aerated classrooms on writing learning. The analyzed findings show that while many teachers saw the value of having displays in class; these were rarely used in the practical teaching of writing a sign that the presence of displays had little influence on writing instruction. These findings are in line with those of Fisher (2008) who studied how 3rd-grade teachers use the physical classroom environment as they implement a balanced literacy program in order to improve their learners' literacy outcomes. Through interviewing teachers and learners and studying the displays in the classroom, Fisher found out that the classes were also full of displays and teachers believed that displays provided materials which learners can refer to (p.57) through the use of the word 'can' implied that these teachers did not actually see learners refer to them. This study supports our findings that teacher's belief in the influence of displays in writing learning. However, as Fisher didn't study ongoing literacy lessons, it is possible that learners referred to them in her absence.

Our findings are also supported by the Suleman Q and Hussain. I (2014)'s research. In their study of the effects of physical classroom environments on academic scores of secondary school learners, Suleman and Hussain found out that classrooms full of displays and whiteboards enhanced teacher's instruction efficiency and learners' attentiveness, interest and motivation. However, Suleman and Hussain did not study if displays were used and how. Our findings portray that their presence had the potential to influence writing instruction if they were used during the teaching and learning of writing.

Billen (2010) used a mixed methods approach to study the nature of elementary writing instruction and physical classroom environments in eight Utah districts. Her findings indicated that writing environments were generally not rich implying that there were few displays which supported writing learning. This is in line with our findings in the majority of classes in where there were no displays much as teachers seemed to support their use.

Hannah (2013) wrote about the effect of the classroom environment on student learning. She said hanging learners work supports writing learning by building rapport between learners and teacher and showing learners what the acceptable writing standards are basing on what is hung. This goes on to show that displays influence writing learning. Most of these studies talk about the presence of displays but not their usage. Our findings portray that even when classrooms were full of displays on good writing, they did little to support writing learning as we did not see teachers use them or learners refer to them in their writing.

Vygotsky 1978 said that some of the tools which support learning include writing. This would imply that the presence of displays of learners' written work would motivate the learners to study good writing skills and use them as samples to motivate them to practice writing. The fact that most classrooms do not have displays and even where they existed, we did not see how they influenced writing instruction and learning means two things: that teachers displayed work on topics they had already taught and hence they saw no need to refer to them. Secondly, that though teachers knew the importance of displays, they did not know how to utilize them to support writing instruction and learning. They took it for granted that their presence would indirectly support the skills.

On the influence of classroom design on writing instruction and learning, findings portrayed that most classes relied on natural light from the windows and electricity to provide light. Findings also portrayed that a well aerated and cool and well-lit classroom could enhance writing and writing instruction where there are no distractions. The presence of big windows in some classes which provide light and fresh air made the environment cool and conducive to concentrate on generating ideas and writing. But where the windows faced a busy noisy place, were shut or had curtains, they provided distractions or made the classroom too stuffy and dark for writing instruction and learning to be effective. Since Vygotsky (1978) says that meaningful language learning takes place in the environment, this implies that the environment should have enough light and air while removing all distracters to learning.

The influence of light on instruction was one of the variables studied by Hill and Kathryn (2010) in their survey on the impact of environmental factors on individual student satisfaction in a university environment. Their study found out that the physical characteristics most related to student satisfaction were sitting and lighting. Though none of these variables significantly affected learners performance, learners in classes where there was adequate light highly rated the instruction methods highly much as there was no difference in the kind of instruction and content between the upgraded 
classes and the other ones. Their study confirms that good lighting makes learners comfortable and more willing to learn which is in line with the findings of our study.

Hannah (2013) in her paper on the effect of classroom environments on student learning wrote that light and sound can either enhance or distract learners' concentration. Though she did not give details on how each of these elements affects writing, her study is in line with our study on the elements of classroom design that promote learning and that teachers should do their best to control them. Her study is also in agreement with our study that classes which are too warm, too cold or with poor circulation of air make learners sluggish and inattentive thus hindering learning.

Our study is also in line with that of Suleman and Hussain (2010) who used an experimental pre-test post-test design to study the effects of physical classroom environments on academic achievement scores of secondary school learners. Though they did not study each of the physical environment variables independently, they found out that proper lighting and ventilation influenced learners' learning and achievement.

\section{CONCLUSIONS AND RECOMMENDATIONS}

In this study, we set out to understand the influence of physical classroom environments on writing instruction and learning. The elements of the physical classroom environments we studied were: classroom displays, the nature of lighting and aeration. We discovered that each of these had varying influences on writing instruction and learning. However, we found out that the influence largely depended on how teachers adapted to their environments when teaching thus concluding that though the physical classroom environment plays an important role in writing instruction and learning, its usage is more important. Therefore, there is a need to train teachers on how to maximize the use of their given classroom environments. School principals should be encouraged in providing good classroom environments for learning, for example, reducing the number of learners in each class.

\section{REFERENCES}

[1] Billen, Monica.T. (2010). The Nature of Classroom Instruction and Physical Environments That Support Elementary Writing. All Theses and Dissertations. https://scholarsachive.byu.edu/etd/2106 (accessed 14/04/ 2018).

[2] Cresswell, J.W. (2014). Research designs, qualitative, quantitative and mixed approaches. $4^{\text {th }}$ Edition. Sage Publications Limited. The United States of America.

[3] Educational Planning Department. (2004). Educational Sector Strategic Plan (2004-2015). retrieved from http://www.africanchildforum.org/c/r/policy\%20\%/uganda/uganda- education-2004-2015-en.pdf (accessed 16/06/2016).

[4] Fisher, E. (2008). The effect of the physical classroom environment on literacy outcomes. How Grade 3 teachers use the physical classroom to implement a balanced literacy curriculum. Masters of Science dissertation submitted to graduate school, University Missouri. https://www.researchgate.net (accessed 1/04/2018).

[5] Hannah, R. (2013). The Effect of Classroom Environment on Student Learning. Retrieved from https://scholarworks.wmich.edu/honors_theses/ 2375 (accessed 2/04/2018).

[6] Hill, M. C., and Kathryn K. E. (2010). The Impact of Physical Classroom Environment on Student Satisfaction and Student Evaluation of Teaching in the University Environment. Academy of Educational Leadership Journal 14: 65-79

[7] Karooro, O. M. (2000). Ugandans and their funny English. In The Monitor, September 22, 1999, Kampala.

[8] Kyalikunda, J. (2005). Interactive techniques in writing instruction: getting students to Communicate in writing. Unpublished Ph.D. dissertation, Makerere University, Kampala.

[9] Ojijo, P. (2012). Review of Education Policy in Uganda. A working paper submitted to the young leaders Think Tank for Policy Alternatives. Retrieved from http://www.slideshare.net/ojijop/review-of-education-policy-in-uganda (accessed 12/02/2014).

[10] Online Education Encyclopedia. The teaching of writing: history, issues, and trends in school-based writing instruction. Retrieved from 〈a'href= "http://education.stateuniversity.com/pages/2552/Writing-Teaching.html"〉 (accessed 15/03/ 2014).

[11] Punch, K. F. (2012). Developing effective research proposals. Sage Publications Limited. London. Britain.

[12] Ssebbunga-Masembe, C. (2001). The state of the use, teaching, and learning of the English language in Uganda's education system. Uganda's Journal of Education, Vol. 3. 1-17.

[13] Suleman, Q; Ishtiaq, H. (2014). The effect of classroom physical environment on the academic achievement scores of secondary school students in Kohat Division, Pakistan. International Journal of Learning and Development. Vol 4 No. 1 P. 71 82

[14] Turuk, M. (2008). The relevance and implications of Vygostky's social-cultural theory in Second language classroom. ARECLS. Vol 5. 244-262.

[15] Vygotsky, L.S. (1978). Mind in society: Development of higher psychological processes. Cambridge MA: Harvard University Press.

[16] Yin, R. (2009). Case study research methods. Sage Publications Inc. California.

Nancy R. Nabiryo is a doctoral student in the department of Humanities and Language Education, Makerere University, Uganda. She was born on $5^{\text {th }}$ June 1981 in Kenya. She earned her Bachelor of Education degree in 2004 and later a Masters of Education degree with a special focus on Language and Literature Education. She is currently working on her Ph.D. project on the value of classroom cultures in writing instruction. Her interests are teaching, reading and touring. 
Samuel Sekiziyivu holds a Ph.D. in Education from Makerere University Uganda and is currently Senior Lecturer in the Department of Humanities and Language Education, Makerere University, Uganda, where he is specialized as a German language teacher trainer. In addition to teacher training, Dr. Sekiziyivu is actively involved in research supervision of graduate students of Makerere University. His interests are language research and teaching. 